OPTOELECTRONIC DEVICES AND

OPTICAL IMAGING TECHNIQUES 
Other Titles in Electrical and Electronic Engineering

G. B. Clayton, EXPERIMENTS WITH OPERATIONAL AMPLIFIERS

G. B. Clayton, LINEAR INTEGRATED CIRCUIT APPLICATIONS

J. C. Cluley, ELECTRONIC EQUIPMENT RELIABILITY

R. F. W. Coates, MODERN COMMUNICATION SYSTEMS

A. R. Daniels, INTRODUCTION TO ELECTRICAL MACHINES

C. W. Davidson, TRANSMISSION LINES FOR COMMUNICATIONS

W. Gosling, A FIRST COURSE IN APPLIED ELECTRONICS

B. A. Gregory, AN INTRODUCTION TO ELECTRICAL INSTRUMENTATION Paul A. Lynn, AN INTRODUCTION TO THE ANALYSIS AND PROCESSING OF SIGNALS

A. G. Martin and F. W. Stephenson, LINEAR MICROELECTRONIC SYSTEMS

R. G. Meadows, ELECTRICAL COMMUNICATIONS Theory, worked examples and problems

J. E. Parton and S. J. T. Owen, APPLIED ELECTROMAGNETICS

A. Potton, AN INTRODUCTION TO DIGITAL LOGIC

J. T. Wallmark and L. G. Carlstedt, FIELD-EFFECT TRANSISTORS IN INTEGRATED CIRCUITS

G. Williams, AN INTRODUCTION TO ELECTRICAL CIRCUIT THEORY 


\section{OPTOELECTRONIC DEVICES AND OPTICAL IMAGING TECHNIQUES}

DOUGLAS A. ROSS

Queen Mary College,

London 
(C) Douglas A. Ross 1979

Softcover reprint of the hardcover 1st edition 1979

All rights reserved. No part of this publication may be reproduced or transmitted, in any form or by any means, without permission.

First published 1979 by

THE MACMILLAN PRESS LTD

London and Basingstoke

Associated companies in Delhi Dublin

Hong Kong Johannesburg Lagos Melbourne

New York Singapore and Tokyo

Typeset in 10/12 Press Roman by

Styleset Limited, Salisbury, Wilts.

\section{British Library Cataloguing in Publication Data}

Ross, Douglas A

Optoelectronic devices and optical imaging techniques.

1. Electrooptical devices

I. Title

621.36 TA1750

ISBN 978-0-333-25335-9

DOI $10.1007 / 978-1-349-16219-2$

ISBN 978-1-349-16219-2 (eBook)

This book is sold subject to the standard conditions of the Net Book Agreement.

The paperback edition of this book is sold subject to the condition that it shall not, by way of trade or otherwise, be lent, resold, hired out, or otherwise circulated without the publisher's prior consent in any form of binding or cover other than that in which it is published and without a similar condition including this condition being imposed on the subsequent purchaser. 
This book is dedicated to Milton Paul Daniel 


\section{Contents}

Preface $x$

1. Photons and Matter 1

1.1 Introduction 1

1.2 Photons 1

1.3 Energy Diagrams 2

$\begin{array}{lll}1.4 & \text { Charge Mobility } & 7\end{array}$

1.5 Absorption 9

2. The Light Emitting Diode 11

2.1 Electroluminescent Devices 11

22 The Light Emitting Diode (LED) 13

2.2 The Light Emitting Diode (LED) 16

$\begin{array}{lll}2.3 \text { LED Modulator } & 17\end{array}$

$\begin{array}{lll}2.4 & \text { LED Optically Coupled Isolators } & 18\end{array}$

2.5 LED Lamps and Displays

3. Solid State Photodetectors - The Photoconductor 20

$\begin{array}{lll}3.1 & \text { Introduction } & 20\end{array}$

3.2 The Photoconductor 20

3.3 The Photoconduction Process 21

$\begin{array}{lll}3.4 & \text { Quantum Efficiency } & 24\end{array}$

3.5 Photoconductor Responsivity 25

3.6 Frequency Response of a Photoconductor 26

3.7 Equivalent Circuit of a Photoconductor 29

4. Solid State Photodetectors - The Photodiode and Phototransistor 31

$\begin{array}{lll}4.1 & \text { Introduction } & 31\end{array}$

4.2 The Depletion Region Photodiode 31

4.3 Current Responsivity of a PIN Photodiode 35

4.4 Frequency Response of a PIN Photodiode 36

4.5 The Photodiode Preamplifier 39

4.6 Photovoltaic Operation of the Photodiode 40

4.7 The Avalanche Photodiode 43

4.8 The Phototransistor 44 
5. Noise in Optoelectronic Devices 48

$\begin{array}{lll}5.1 & \text { Introduction } & 48\end{array}$

$\begin{array}{ll}5.2 \text { Definitions } & 49\end{array}$

5.3 Thermal Noise $\quad 53$

5.4 The Bandwidth of Thermal Noise 55

5.5 Noise Sources in Circuits $\quad 56$

$\begin{array}{lll}5.6 & \text { Shot Noise } & 57\end{array}$

5.7 Signal-to-noise Ratio in Photodetectors 60

5.8 Noise Equivalent Power (NEP) 62

5.9 Evaluation of a Photodiode Preamplifier 64

6. The Solar Cell 68

$\begin{array}{lll}6.1 & \text { Introduction } & 68\end{array}$

6.2 The $n$ on $p$ Silicon Photovoltaic Cell 68

$\begin{array}{ll}\text { 6.3 Current-Voltage Characteristics } & 71\end{array}$

6.4 Series Resistance Loss $\quad 73$

6.5 Spectral Characteristics of the Silicon Solar Cell 75

6.6 Spectrum of Solar Radiation and Atmospheric Absorption 77

6.7 Photocurrent and Power Conversion Efficiency 79

6.8 Can Solar Cell Efficiency be Increased? 81

6.9 The Economics of Solar Cells $\quad 84$

7. The Laser Diode 86

$\begin{array}{lll}7.1 & \text { Introduction } & 86\end{array}$

$\begin{array}{lll}7.2 & \text { Stimulated Emission } & 87\end{array}$

7.3 The Double Heterostructure Laser Diode 88

7.4 Radiation from a Stripe Geometry Double Heterostructure 91 Laser Diode $\quad 95$

7.5 Spectral Properties of the Laser Diode 99

7.6 Coherence Length of the Laser Diode 101

7.7 The Effect of Many Longitudinal Modes 102

7.8 Longitudinal Modes and Dispersion

8. Optical Imaging Techniques 105

$\begin{array}{lll}8.1 \text { Introduction } & 105\end{array}$

8.2 Photographic Film 105

$\begin{array}{ll}\text { 8.3 Noise on Photographic Film } & 107\end{array}$

8.4 The Signal-to-noise Ratio of Film 109

8.5 Information Capacity of Photographic Film 110 
8.6 Holography

113

8.7 Viewing the Hologram 117

8.8 The Modulation Transfer Function 119

8.9 The Charge Coupled Device Area Image Sensor 120

8.10 Information Capacity of a CCD Image Sensing Array 125

Appendix A Photometric Units 126

Appendix B Physical Constants 131

References $\quad 132$

Index 135 


\section{Preface}

The technology of optoelectronics, which deals with devices combining optical and electrical ports, has expanded enormously in the past few years, as a result of the rapid expansion of the semiconductor industry. Some optoelectronic devices, such as the light emitting diode or LED, have found their way into the majority of electronic appliances manufactured today. This rather radical change from tungsten filament light sources, producing more heat than light, to LEDs producing highly coloured or monochromatic light, has taken place almost without comment.

The fact that the present age could be described as the era of the crystalline semiconductor is reflected in the variety of optoelectronic devices. Almost every function which formerly required expensive photosensitive or photoemissive devices operating at high voltages, can now be accomplished with an inexpensive semiconductor device requiring a few volts. The photomultiplier tube can be replaced by the photodiode/operational amplifier; the gas laser by the laser diode; the cathode ray oscilloscope by the LED display; the television camera by the charge coupled device area sensor; and they can all be powered by another optoelectronic device, the solar cell.

This book is written in a spirit of excitement and wonder at the ingenuity of man to develop new solutions to old problems. It is hoped that the reader may sense some of the author's enthusiasm, and may even be carried away to develop his own interest in optoelectronics. The book is written at a level which should be accessible to the undergraduate student with some understanding of semiconductor physics and electronic circuits. The more difficult topics in the book are included for completeness and for the reader who wants to develop more than a superficial understanding.

The devices described here reflect the author's interests and are not meant to provide an encyclopedic coverage of the subject. None the less, it is hoped that a representative collection of devices has been included, and that these will maintain their importance in the future. It is the task of the present generation of engineering and physics students to solve some of the many problems hinted at here; this is, after all, only a beginning. 